\title{
The F Plasmid Carries an IS3 Insertion Within finO
}

\author{
By KEAT-CHYE CHEAH AND RON SKURRAY* \\ Department of Microbiology, Monash University, Clayton, Victoria 3168, Australia
}

(Received 24 April 1986)

DNA-DNA hybridization studies support the conclusion that coding sequences of the fertility inhibition gene, finO, are present on the $\mathrm{F}$ plasmid and map downstream of the transfer region, entirely within $99 \cdot 19-2 \cdot 0 \mathrm{~F}$. In addition, the results indicate that the IS3a element at $100 / 0$ $1.26 \mathrm{~F}$ is inserted within the $\mathrm{F}$ fin $O$ coding region. This insertion may have inactivated the $f$ in $O$ gene on the $\mathrm{F}$ plasmid.

\section{INTRODUCTION}

Electron microscopic heteroduplex studies have demonstrated that the transfer $($ tra $)$ regions on F and on the F-like plasmids R1 and R6-5 are extensively, but not completely, homologous (Sharp et al., 1973). The expression of the majority of the tra genes on these plasmids is positively controlled by the product of traJ (Willetts \& Skurray, 1980). Expression of traJ is, in turn, negatively regulated by the FinOP fertility inhibition system, which depends upon the products of the finO and finP genes (Finnegan \& Willetts, 1972; Willetts, 1977).

The fin $P$ gene of $F$ maps between traM and traJ (Fig. 1) and it has been proposed that the product of fin $P$ is an RNA molecule, encoded within the traJ leader sequence, which interacts with the finO product to inhibit transcription and/or translation of traJ (Mullineaux \& Willetts, 1985); finP on R6-5 is located in an analogous position to that on F (Timmis et al., 1978). We have previously reported the cloning of the R6-5 finO region into pBR322, yielding the plasmid pRS3509; DNA deletion analysis and transposon Tn 5 mutagenesis of pRS3509 have allowed us to precisely map the $f i n O$ gene within the coordinates 94.0-94.85 R6-5 (Cheah et al., 1984; Fig. 2). A $22 \mathrm{kDa}$ protein has been tentatively identified as the R6-5 finO product (Timmis et al., 1978), although it should be noted that further experimentation by these authors, and others (Dempsey \& McIntire, 1983; Cheah et al., 1984), has failed to resolve this polypeptide.

Since F-like plasmids such as R1, R6-5 and R 100 constitutively specify the finO and finP products, the transfer systems of these plasmids are naturally repressed by the FinOP system (Finnegan \& Willetts, 1972); the conjugal transfer frequency exhibited by these F-like plasmids is approximately $0 \cdot 1-1 \%$ that of $\mathrm{F}$. However, conjugally derepressed $\mathrm{FinO}^{-}$mutants, such as R100-1 (Egawa \& Hirota, 1962) and R1drd-19 (Meynell \& Datta, 1967), that transfer at a similar level to $\mathrm{F}$ have been isolated. The transfer proficient $f i n P^{+} \mathrm{F}$ plasmid is believed to be a naturally occurring fin $O$ mutant; in the presence of a co-resident $\mathrm{FinO}^{+} \mathrm{F}$-like plasmid, the $\mathrm{F}$ plasmid is also repressed for DNA transfer (Willetts, 1977).

To date there have been no reported attempts to clarify the exact status of fin $O$ sequences on the $F$ plasmid, nor to establish if they are in fact present at all. Interpretation of the R6-5/F heteroduplex data of Sharp et al. (1973), in the light of our localization of finO sequences on R6-5 (Cheah et al., 1984), did, however, lead us to speculate that finO sequences may well be present on F; a similar proposal has been put forward independently by Clark (1985). In this paper, we examine this hypothesis and describe the use of fin $O$-specific DNA probes derived from R6-5 to locate $f$ in $O$ sequences on $\mathrm{F}$. 


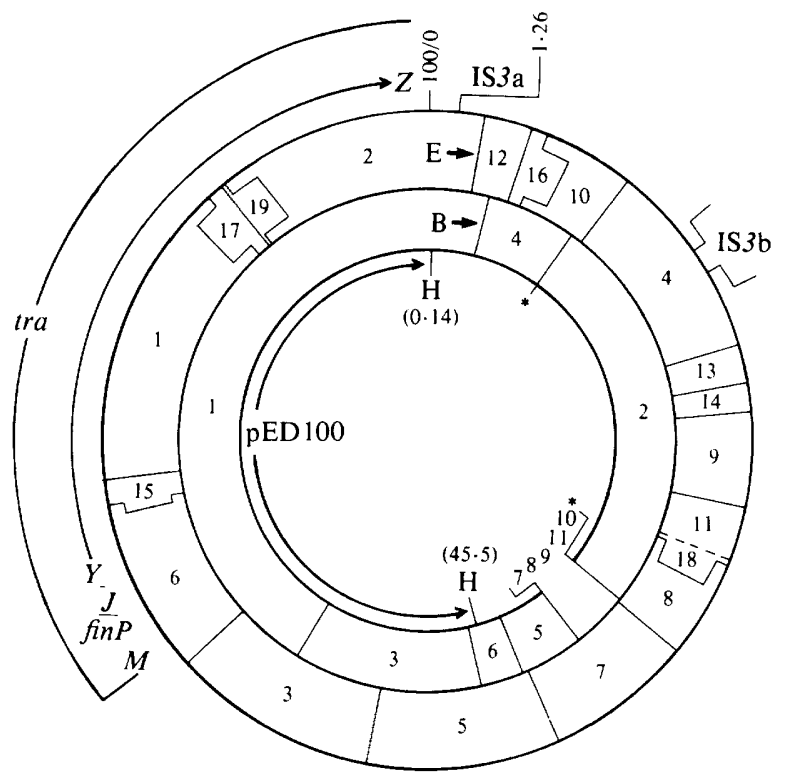

Fig. 1. Physical map of the F plasmid. The locations of EcoRI (E) and BamHI (B) sites, as well as the positions of IS3 elements, taken largely from Skurray et al. (1978), have been adjusted to fit a $100 \mathrm{~kb}$ map of $F$. The BamHI fragments of F, with the exception of $\mathrm{f} 11$, have been cloned, and their map positions precisely determined; the location of a twelfth BamHI fragment $(0.075 \mathrm{~kb})$ has not been determined but it must lie at either of the positions indicated by an asterisk (D. Cram \& R. Skurray, unpublished data). The positions of fin $P$ and the transfer (tra) operons $\operatorname{tra} M, \operatorname{tra} J$ and $\operatorname{tra} Y \rightarrow Z$ are shown (Willetts \& Skurray, 1980); the size of IS3 $(1.26 \mathrm{~kb})$ is taken from the sequence data of Timmerman \& Tu (1985). Recircularization of the largest HindIII (H) fragment $(0 \cdot 14-45 \cdot 5 \mathrm{~F})$ of $\mathrm{F}$ generated pED100, which is self replicative and carries the entire transfer region (Willetts \& Johnson, 1981).

\section{METHODS}

Plasmids. Plasmids used, in addition to F, were pED100 (Fig. 1; consists of recircularized 0.14-45.5 F HindIII fragment of the F plasmid) (Willetts \& Johnson, 1981); pSH2 (EcoRI fragment $\mathrm{f} 2$ of $\mathrm{F}$ cloned into RSF2124) (Achtman et al., 1978); pRS3509 (92.75-95.55 R6-5 finO+ BamHI fragment cloned into pBR322), pRS3509:: Tn5 derivatives (pRS3565 and pRS3583) (Cheah et al., 1984).

Preparation and analysis of DNA. Purified low copy number plasmid DNA (F and pED100) was obtained using a Triton X-100 cleared lysate polyethylene glycol precipitation procedure, followed by banding on caesium chloride/ethidium bromide density gradients, essentially as described by Humphreys et al. (1975) and Kahn et al. (1979). Isolation of amplifiable plasmid DNA, digestion with restriction endonucleases and agarose gel electrophoresis were done according to Ray \& Skurray (1983). Fragment sizes of pBR322 DNA digested with TaqI and $\lambda$ phage DNA cleaved with $H$ indIII, for use as standards, were taken from Sutcliffe (1978) and Daniels et al. (1983), respectively.

DNA-DNA hybridization. Bidirectional transfer of DNA from an agarose gel to nitrocellulose filter papers (Schleicher and Schüll) was done by the method of Smith \& Summers (1980). DNA fragments from low melting point agarose gel (Biorad) were extracted essentially as described by Langridge et al. (1980). Purified DNA was radiolabelled with $\left[\alpha^{-32} \mathrm{P}\right] \mathrm{dATP}\left(1800 \mathrm{Ci} \mathrm{mmol}^{-1}, 66600 \mathrm{GBq} \mathrm{mmol}^{-1}\right.$; Biotechnology Research Enterprises SA) by nick translation and hybridized with nitrocellulose filters containing target DNA (Maniatis et al., 1982). Washed and dried filters were then exposed to Fuji RX film at $-70^{\circ} \mathrm{C}$ for sufficient time to produce an acceptable autoradiograph.

\section{RESULTS AND DISCUSSION}

\section{Homology between $F$ and the $R 6-5$ finO region}

To establish whether the F plasmid (Fig. 1) does indeed possess DNA sequences homologous to the R6-5 finO region, the pRS3509 Bam HI fragment that carries the entire R6-5 finO region $(92.75-95.55$ R6-5, Fig. 2$)$ was labelled with $[\alpha-32 \mathrm{P}] \mathrm{dATP}$ by nick translation, and hybridized to a 


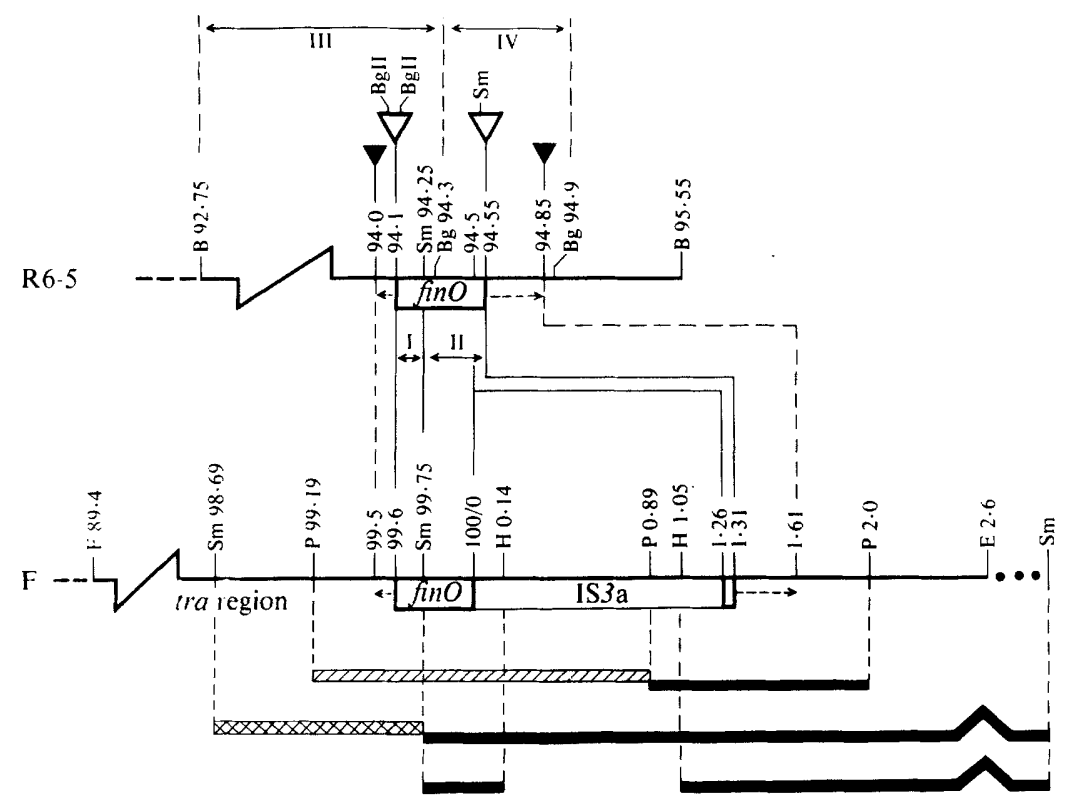

Fig. 2. Physical map of R6-5 and $\mathrm{F}$ finO regions. The relevant restriction sites (B, Bam HI ; Bg, Bg/I; Sm, Smal), R6-5 coordinates and positions of Tn 5 insertions (phenotype: $\nabla$, FinO ${ }^{+} ; \nabla$, FinO ${ }^{-}$) on the fin $\mathrm{O}^{+}$92.75-95.55 R6-5 BamHI fragment of pRS3509 are taken from Cheah $e$ al . (1984). The $B g / \mathrm{II}$ (BgII) and SmaI sites of Tn5 (Jorgensen et al., 1979) used in the construction of probes, as decribed in the text, are shown on the open triangles. The minimum span of R6-5 fin $O$ coding sequences is indicated by the open box (94-1-94.55 R6-5); broken arrowed lines on either side of finO (94-0-94-85 R6-5) depict the maximum extent of the gene. Only the relevant portion of EcoRI fragment $\mathrm{F} 2$ of F (89.4-2.6 F), which includes the distal part of the transfer (tra) region and IS 3 a $(100 / 0-1.26 \mathrm{~F})$, is shown; the restriction sites for EcoRI (E), HindIII (H), Pst (P) and SmaI (Sm) are given (Willetts \& Johnson, 1979; Willetts \& Skurray, 1980; Manning et al., 1982). Dots leading to the SmaI site to the right of the EcoRI site at $2.6 \mathrm{~F}$ denote $1.3 \mathrm{~kb}$ of RSF2124 vector sequences on pSH2, the source of F DNA used in the hybridization experiments described in Fig. 4. $\triangle \times$, DNA fragment that hybridized to the $f$ in $O$-specific probe I (94-1-94-25 R6-5); , DNA fragments that hybridized to the finO-specific probe II (94.2594.55 R6-5); $\square]$, PstI fragment that hybridized to both probes. Other probes used were III (92.7594-3 R6-5) and IV (94-3-94.9 R6-5). The fin $O$ regions of R6-5 and F are aligned relative to the SmaI sites at $94.25 \mathrm{R} 6-5$ and $99.75 \mathrm{~F}$ (see text). The open boxes at $99 \cdot 6-100 / 0 \mathrm{~F}$ and $1.26-1.31 \mathrm{~F}$ indicate the presumed minimum span of $f$ in $O$ sequences on $\mathrm{F}$ on either side of IS3a; the deduced maximum extent $(99.5-1.61 \mathrm{~F})$ of $\mathrm{F}$ finO coding sequences is indicated by broken arrowed lines.

nitrocellulose filter containing BamHI and EcoRI restriction fragments of F DNA (Fig. 3). The resulting autoradiograph (Fig. 3 b) showed that this $f i n O^{+}$fragment hybridized only to the $42 \mathrm{~kb}$ BamHI fragment f1 of F (lane A), within which lies F EcoRI fragments f1, f2, f6, f15, f17, f19 and parts of $\mathrm{f} 3$ and $\mathrm{f} 12$ (Skurray et al., 1978; Fig. 1). Of the latter EcoRI fragments, only f1 $(14.2 \mathrm{~kb})$ or $\mathrm{f} 2(13.2 \mathrm{~kb})$, or both, showed homology with the $\mathrm{finO}^{+}$fragment (Fig. $3 b$, lane B); the close migration of fragments $\mathrm{f} 1$ and $\mathrm{f} 2$ (Fig. $3 a$, lane $\mathrm{B}$ ) made it difficult to distinguish between these possibilities. To resolve this, the EcoRI-digested products of pED100, a selfreplicative $\mathrm{Tra}^{+}$derivative of the F plasmid which consists of $F$ EcoRI fragments f1, f3, f6, f15, $\mathrm{f} 17, \mathrm{f} 19$ and parts of $\mathrm{f} 2$ ( $\overline{\mathrm{f}}$ ) and $\mathrm{f} 5$ ( $\overline{\mathrm{f} 5}$ ) (Willetts \& Johnson, 1981; Fig. 1), were hybridized with the $\mathrm{finO}^{+}$fragment (Fig. 3, lane C). Whereas $E c o$ RI fragment $\mathrm{fl}$ did not hybridize to the finO $^{+}$ fragment, the $21 \mathrm{~kb} E c o R I \overline{\mathrm{f}}-\overline{\mathrm{f} 5}$ fusion fragment from pED100 (Willetts \& Johnson, 1981) did. These data indicate that the EcoRI fragment which hybridized with the $f_{i n O^{+}}$fragment in Fig. 3 (b) lane $\mathrm{B}$ is $\mathrm{f}$. 


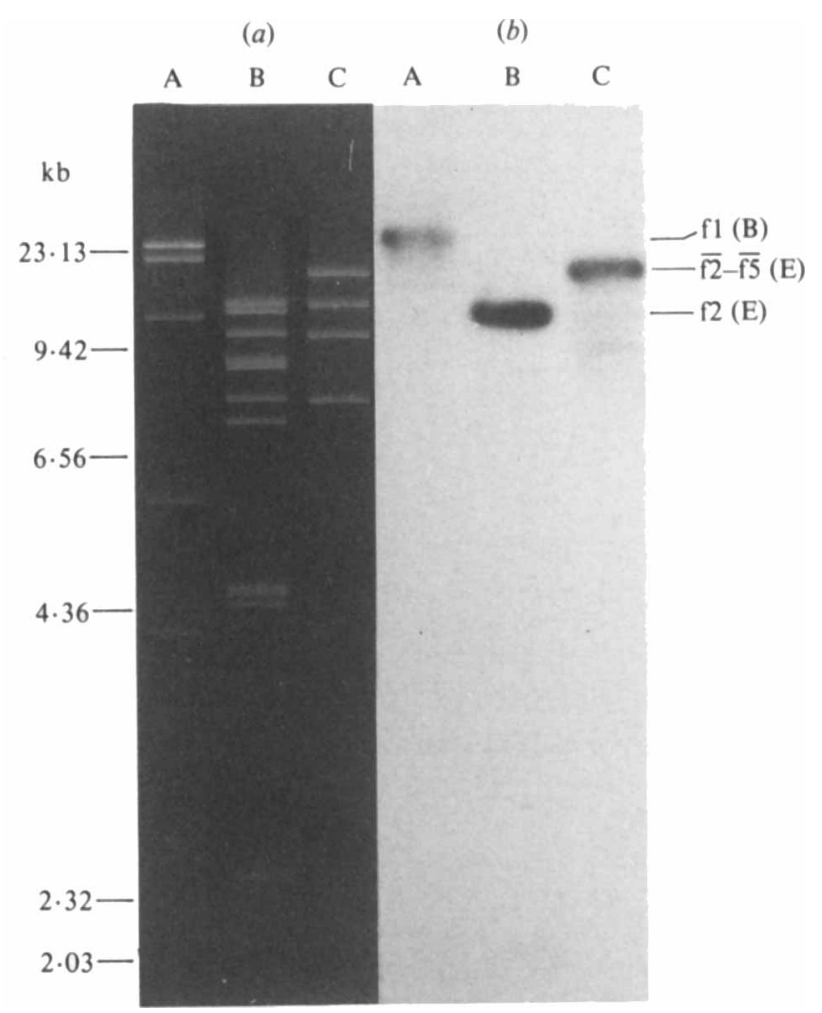

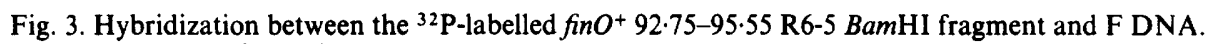
(a) Agarose gel $(0.7 \%$, w/v) electrophoresis of F DNA digested with either BamHI (lane A) or EcoRI (lane B); lane C contains EcoRI-digested pED100. Six of the twelve BamHI fragments of F are visible on this gel (lane A) as are eleven of the nineteen $E c o$ RI fragments of $F$ (lane B). $\lambda$ phage DNA digested with HindIII was included in this gel; the positions of migration and sizes in kb of the DNA fragments generated are shown at the left. The positions of relevant BamHI (B) and EcoRI (E) fragments of F are indicated at the right. $(b)$ Autoradiograph of the nitrocellulose filter containing the DNA fragments shown in $(a)$ after hybridization with the ${ }^{32} \mathrm{P}$-labelled in $^{+}$fragment.

\section{Location of finO sequences on the $F$ plasmid}

To confirm that EcoRI fragment $\mathrm{f} 2$ of $\mathrm{F}$ possesses $f$ in $O$ sequences, and to determine the organization of $f i n O$ on $\mathrm{F}$, two finO-specific DNA probes encompassing different segments of the R6-5 finO gene were chosen. DNA fragments containing fin $O$ sequences were obtained from two FinO $^{-}$pRS3509 derivatives with transposon Tn5 insertions in R6-5 finO sequences at 94.1 R6-5 (pRS3565) and 94.55 R6-5 (pRS3583) (Cheah et al., 1984; Fig. 2). Purification of the appropriate DNA fragments after $B g / \mathrm{II}-S m a I$ digestion of pRS3565 and SmaI cleavage of pRS3583 provided the R6-5 finO : : Tn5 fusion fragments containing 94.1-94.25 R6-5 (probe I) and 94.25-94.55 R6-5 (probe II) finO sequences, respectively (Fig. 2). Each probe also carried at least $1.55 \mathrm{~kb}$ of $\operatorname{Tn} 5$ sequences but, as expected, our preliminary hybridization experiments demonstrated that $E c o \mathrm{RI}$ fragment $\mathrm{f} 2$ of $\mathrm{F}$ lacked sequence homology with $\operatorname{Tn} 5$ (data not shown) and therefore any hybridization observed with the finO probes derived from either pRS3565 or pRS3583 should result from homology between $\mathrm{F}$ and sequences within the R6-5 finO gene.

${ }^{32} \mathrm{P}$-Labelled probes I and II were incubated separately with nitrocellulose filters containing pSH2 DNA (EcoRI fragment $\mathrm{f} 2$ cloned into RSF2124; Achtman et al., 1978) that had been digested with PstI, SmaI or HindIII-SmaI (Fig. $4 b$ and $c$ ); a summary of the hybridization results, aligned to the map of $\mathrm{F}$, is presented in Fig. 2. Both of the fin $O$-specific probes hybridized to the $1.7 \mathrm{~kb}(99.19-0.89 \mathrm{~F})$ Pst I fragment (Fig. $4 b$ and $c$, lane A) which encompasses 


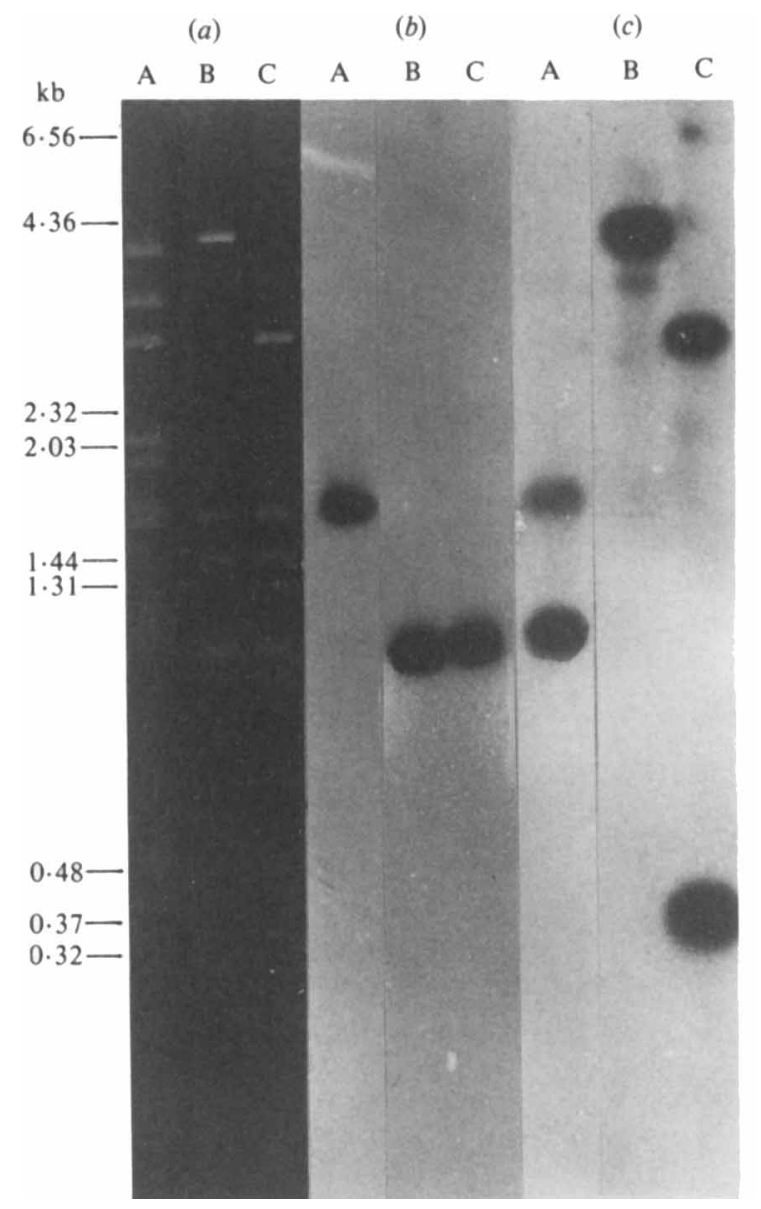

Fig. 4. Location of $f$ in $O$ sequences on the F plasmid. (a) An agarose gel $(1 \%$, w/v) showing the products of pSH2 DNA digested with Pst (lane A), SmaI (lane B) and HindIII-SmaI (lane C). $\lambda$ pl age DNA and pBR322 DNA cleaved with HindIII and TaqI, respectively, were included in this gel and the positions of migration of relevant DNA fragments and sizes in $\mathrm{kb}$ are shown on the left. DNA from the agarose gel was transferred to nitrocellulose filters and hybridized with ${ }^{32} \mathrm{P}$-labelled R6-5 finO-specific probe I (b) and probe II (c).

sequences to the left of IS3a and includes some of the IS3a sequence (Fig. 2). The $1 \cdot 11 \mathrm{~kb}(0 \cdot 89$ $2.0 \mathrm{~F}$ ) Pst $\mathrm{I}$ fragment encompasses the right hand portion of IS $3 \mathrm{a}$ and the adjacent $\mathrm{F}$ sequences (Fig. 2), and hybridized only to probe II (Fig. $4 c$, lane A). Neither probe I nor probe II hybridized to the $0.91 \mathrm{~kb}(0.14-1.05 \mathrm{~F})$ HindIII fragment (Fig. 4, lane C) that is completely internal to IS3a (Fig. 2), but is should be noted that there are at least $0.14 \mathrm{~kb}$ of IS3a sequences on the 1.11 and $1.7 \mathrm{~kb}$ PstI fragments that did hybridize with these fin $O$-specific probes (Fig. 2). The fact that F EcoRI fragment f4, which contains the entire IS3b sequence (Hu et al., 1975; Skurray et al., 1978; Fig. 1), failed to hybridize to the $\mathrm{BamHI}$ finO ${ }^{+}$fragment (Fig. 3, lane B) precludes the involvement of IS3a sequences in the hybridization results shown in Figs 2 and 3.

Taken together, these results confirm that $E c o$ RI fragment $\mathrm{f} 2$ of $\mathrm{F}$ carries finO sequences. In addition, the data indicate that the IS3a sequences between $100 / 0 \mathrm{~F}$ and $1.26 \mathrm{~F}$ divide the $\mathrm{F}$ fin $O$ sequences into two portions (Fig. 2).

Both probe I and II were derived by digestion at the 94.25 R6-5 SmaI site (Fig. 2). Whereas probe I hybridized to the $1.06 \mathrm{~kb}(98.69-99.75 \mathrm{~F}) \mathrm{SmaI}$ fragment (Fig. $4 b$, lanes B and C), probe II hybridized with the $0.39 \mathrm{~kb}(99 \cdot 75-0 \cdot 14 \mathrm{~F})$ HindIII-SmaI fragment (Fig. $4 c$, lane C) as well as 
with the $4.15 \mathrm{~kb}$ Smal and the $2.85 \mathrm{~kb}$ HindIII-SmaI fragments, which contained the $99.75-$ $2.6 \mathrm{~F}$ and $1.05-2.6 \mathrm{~F}$ sequences of the F plasmid, respectively (Fig. 2; Fig. $4 c$, lanes B and $\mathrm{C}$ ). These hybridization data coupled with the fact that the probed $\mathrm{F}$ fin $O$ fragments map leftwards and rightwards of the SmaI site at 99.75 F, suggest that the SmaI sites at 94.25 R6-5 and 99.75 F are equivalent; they have been aligned accordingly in Fig. 2.

\section{Defining the boundaries of finO sequences on $F$}

To determine the physical limits of finO coding sequences on either side of IS3a, two further DNA probes (III and IV, Fig. 2), which together encompassed the entire R6-5 finO gene, were used. ${ }^{32} \mathrm{P}$-Labelled probe III and probe IV were incubated separately with pSH2 DNA which had been digested with PstI (data not shown). Probe III hybridized only to the 99.19-0.89 F $P s t \mathrm{I}$ fragment thus delimiting the maximum leftward boundary of $f i n O$ sequences on $\mathrm{F}$ to 99.19 F (Fig. 2). Probe IV, however, hybridized to the 0.89-2.0 F PstI fragment, as well as to the 99.19-0.89 F Pst $\mathrm{I}$ fragment; this indicates that the rightwards limit of finO on $\mathrm{F}$ must be between $0.89 \mathrm{~F}$ and $2.0 \mathrm{~F}$ (Fig. 2). Besides confirming that IS3a sequences at $100 / 0-1.26 \mathrm{~F}$ are bounded by fin $O$ coding sequences, these results conclusively demonstrate that $f$ in $O$ sequences are entirely contained within $99 \cdot 19$ and $2.0 \mathrm{~F}$ (Fig. 2).

The maximum and minimum limits of the R6-5 fin $O$ gene have previously been determined to be 94-0-94.85 R6-5 and 94.1-94.55 R6-5, respectively (Cheah et al., 1984; Fig. 2). By assuming that R6-5 and F finO genes are of approximately the same size, we have been able to align the $\mathrm{F}$ and R6-5 finO coding sequences as shown in Fig. 2. On this basis, we propose (i) that the site of IS 3 a insertion into the $\mathrm{F}$ fin $O$ coding region at $100 / 0 \mathrm{~F}$ is equivalent to $94.5 \mathrm{R} 6-5$ in terms of R6-5 coordinates - indicating that IS3a is indeed inserted into the $\mathrm{F}$ finO structural gene - and (ii) that the maximum and minimum boundaries of fin $O$ coding sequences on $\mathrm{F}$ are between 99.5 $1.61 \mathrm{~F}$ and $99 \cdot 6-1.31 \mathrm{~F}$, respectively (Fig. 2).

\section{Evolution of the $F$ finO gene}

The conjugative plasmids $F$ and R6-5 probably originated from a common ancestor but followed different evolutionary pathways, during which the fin $O$ gene of $F$ was inactivated by an insertion of IS3. Since the excision frequency of IS3 is low $\left(5 \times 10^{-9}\right.$ per cell per generation) (Sommer et al., 1979), a finO : :IS3a mutation would be expected to be relatively stable. In accordance with this, no fin $\mathrm{O}^{+}$revertant of the $\mathrm{F}$ plasmid was detected in studies reported by Beutin \& Achtman (1979). However, the apparent stability of the FinO- state of $\mathrm{F}$ could also result if part of the $f$ in $O$ gene had been deleted, an event which might have occurred in addition to the IS3a insertion; the exact extent of finO sequences on $\mathrm{F}$ must await a comparative DNA sequence analysis of the finO regions on R6-5 and $\mathrm{F}$.

A bacterium harbouring the derepressed $\mathrm{FinO}^{-} \mathrm{F}$ plasmid suffers two disabilities. Firstly, such a cell synthesizes $\mathrm{F}$ pili and is therefore subject to infection by male-specific bacteriophages, and secondly, unnecessary constitutive synthesis of tra gene products would be expected to place the cell in an energetically unfavourable situation relative to $\mathrm{F}^{-}$cells. The survival of the F plasmid suggests that properties expressed by this plasmid over-ride these disadvantages.

We thank Lindsay Ham, Robert Hirst and Adrian Hodgson for useful discussions. K. -C. C. was a recipient of a Monash Graduate Scholarship. This work was supported in part by the Australian Research Grants Scheme.

\section{REFERENCES}

ACHTMan, M., Skurray, R. A., Thompson, R., Helmuth, R., Hall, S., Beutin, L. \& Clark, A. J. (1978). Assignment of tra cistrons to EcoRI fragments of F sex factor DNA. Journal of Bacteriology 133, 1383-1392.

Beutin, L. \& Achtman, M. (1979). Two Escherichia coli chromosomal cistrons, sfr $A$ and $\operatorname{sr} f B$, which are needed for expression of $\mathrm{F}$ factor tra functions. Journal of Bacteriology 139, 730-737.
Cheah, K.-C., Ray, A. \& Skurray, R. (1984). Cloning and molecular analysis of the $f$ in $O$ region from the antibiotic-resistance plasmid R6-5. Plasmid 12, 222226.

Clark, A. J. (1985). Conjugation and its after-effects in E. coli. In The Origins and Evolutions of Sex, pp. 47-68. Edited by H. O. Halvorson \& A. Monroy. New York: Alan R. Liss, Inc.

Daniels, D. L., Schroeder, J. L., Szybalski, W., 
Sanger, F. \& Blatter, F. R. (1983). A molecular map of coliphage lambda. In Lambda $I I$, pp. 469517. Edited by R. W. Hendrix, J. W. Roberts, F. W. Stahl \& R. A. Weisberg. Cold Spring Harbor, NY: Cold Spring Harbor Laboratory.

Dempsey, W. A. \& McIntiRe, S. A. (1983). The finO gene of antibiotic resistance plasmid R100. Molecular and General Genetics 190, 444-451.

EgaWA, R. \& Hirota, Y. (1962). Inhibition of fertility by multiple drug resistance factors $(\mathrm{R})$ in $E$. coli $\mathrm{K}$ 12. Japanese Journal of Genetics 37, 66-69.

FinNegAN, D. \& WilletTs, N. (1972). The nature of the transfer inhibitor of several F-like plasmids. Molecular and General Genetics 119, 57-66.

Hu, S., Ptashne, K., Cohen, S. N. \& Davidson, N. (1975). $\alpha \beta$ sequence of F is IS3. Journal of Bacteriology 123, 687-692.

Humphreys, G. O., Willshaw, A. G. \& Anderson, E. S. (1975). A simple method for the preparation of large quantities of pure plasmid DNA. Biochimica et biophysica acta 383, 457-463.

Jorgensen, R. A., Rothstein, S. J. \& Reznikoff, W. S. (1979). A restriction enzyme cleavage map of $\mathrm{Tn} 5$ and location of a region encoding neomycin resistance. Molecular and General Genetics 177, 6572.

Kahn, M., Kolter, R., Thomas, C., Figurski, D., Meyer, R., Remaut, E. \& Helinski, D. R. (1979). Plasmid cloning vehicles derived from plasmids ColE1, F, R6K, and RK2. Methods in Enzymology 12, 268-280.

LANGRIDGe, J., LANGRIDGe, P. \& Bergquist, P. L. (1980). Extraction of nucleic acids from agarose gels. Analytical Biochemistry 103, 264-271.

Maniatis, T., Fritsch, E. F. \& SambrooK, J. (1982). Molecular Cloning: a Laboratory Manual. Cold Spring Harbor, NY: Cold Spring Harbor Laboratory.

Manning, P. A., Kusecek, B., Morelli, G., Fisseau, C. \& ACHTMAN, M. (1982). Analysis of the promoterdistal region of the tra operon of the F sex factor of Escherichia coli $\mathrm{K}-12$ encoded by $E$ co RI restriction fragments $\mathrm{f} 17, \mathrm{f} 19$ and $\mathrm{f} 2$. Journal of Bacteriology 150, 76-88.

Meynell, E. \& DatTa, N. (1967). Mutant drug resistance factors with a high transmissibility. Nature, London 214, 885-887.

Mullineaux, P. \& Willetts, N. (1985). Promoters in the transfer region of plasmid F. In Plasmids in
Bacteria, pp. 605-614. Edited by D. R. Helinski, S. N. Cohen, D. B. Clewell, D. A. Jackson \& A. Hollaender. New York: Plenum Presss.

RAY, A. \& SKuRray, R. (1983). Cloning and polypeptide analysis of the leading region in F plasmid DNA transfer. Plasmid 9, 262-272.

Sharp, P. A., Cohen, S. N. \& Davidson, N. (1973). Electron microscopic heteroduplex studies of sequence relations among plasmids of Escherichia coli. II. Structure of drug resistance $(R)$ factors and $F$ factors. Journal of Molecular Biology 75, 235-255.

Skurray, R. A., Nagaishi, H. \& Clark, A. J. (1978). Construction and BamHI analysis of chimeric plasmids containing EcoRI DNA fragments of the F sex factor. Plasmid 1, 174-186.

Smith, G. E. \& Summers, M. D. (1980). The bidirectional transfer of DNA and RNA to nitrocellulose or diazobenzyloxymethyl-paper. Analytical Biochemistry 109, 123-129.

Sommer, H., Cullum, J. \& SAedler, H. (1979). Integration of IS3 into IS2 generates a short sequence duplication. Molecular and General Genetics 177, 85-89.

SuTCLIFFE, J. G. (1978). pBR322 restriction map marked from the DNA sequence: accurate DNA size markers up to 4361 nucleotide pairs long. Nucleic Acids Research 5, 2721-2728.

Timmerman, K. P. \& Tu, C.-P. (1985). Complete sequence of IS3. Nucleic Acids Research 13, $2127-$ 2139.

Timmis, K. N., Andrés, I. \& Achtman, M. (1978). Fertility repression of F-like conjugative plasmids. Physical mapping of the R6-5 finO and fin $P$ cistrons and identification of the finO protein. Proceedings of the National Academy of Sciences of the United States of America 75, 5836-5840.

WILleTtS, N. (1977). The transcriptional control of fertility in F-like plasmids. Journal of Molecular Biology 112, 141-148.

WilletTs, N. \& Johnson, D. (1979). R. Smal cleavage map of the transfer region of the $E$. coli $\mathrm{K} 12$ sex factor F. Genetical Research 34, 195-202.

WILletTs, N. \& JohNSON, D. (1981). pED100, a conjugative $\mathrm{F}$ plasmid derivative without insertion sequences. Molecular and General Genetics 182, 520 522.

WilletTs, N. \& SkurRay, R. (1980). The conjugation system of F-like plasmids. Annual Review of Genetics 14, 41-76. 